\title{
ON THE EDGE OF EMPIRE: \\ GENDER, RACE, AND THE MAKING OF BRITISH COLUMBIA, 1849-1871
}

On the Edge of Empire is a well-written, carefully researched, and persuasively argued book that delineates the centrality of race and gender in the making of colonial and national identities, and in the rewriting of Canadian history as colonial history. Utilizing feminist and postcolonial filters, Adele Perry designs a case study of British Columbia. She draws on current work that aims to close the distance between 'home' and 'away' in order to make her case about the commonalities and differences between circumstances in British Columbia and those of the 'Anglo-American' culture that was increasingly dominant in North America, parts of the British Isles, and other white settler colonies.

On the Edge of Empire examines how a loosely connected group of reformers worked to transform an environment that lent itself to two social phenomena: white male homosocial culture and conjugal relationships between First Nations women and settler men. The reformers worked to replace British Columbia's homosocial culture with the practices of respectable, middle-class European masculinity. Others encouraged mixed-race couples to conform to European standards of marrige and discouraged white-Aboriginal unions through moral suasion or the more radical tactic of racially segregated space. Another reform impetus laboured through immigration and land policy to both build and shape the settler population.

A more successful reform effort involved four assisted female immigration efforts, yet the experience of white women in British Columbia only made more pronounced the gap between colonial discourse and colonial experience. In its failure to live up to British expectations, remaining a racially plural resource colony with a unique culture, British Columbia revealed much about the politics of gender, race, and the making of colonial society on this edge of empire.

(Studies in Gender and History)

ADELE PERRY is an assistant professor of history at St Paul's College, University of Manitoba. 


\section{STUDIES IN GENDER AND HISTORY}

General editors: Franca Iacovetta and Karen Dubinsky 


\section{On the Edge of Empire}

Gender, Race, and the

Making of British Columbia,

1849-1871

ADELE PERRY

UNIVERSITY OF TORONTO PRESS

Toronto Buffalo London 
(C) University of Toronto Press Incorporated 2001

Toronto Buffalo London

Printed in Canada

Reprinted 2002, 2004

ISBN 0-8020-4797-1 (cloth)

ISBN 0-8020-8336-6 (paper)

(6)

Printed on acid-free paper

\section{Canadian Cataloguing in Publication Data}

Perry, Adele

On the edge of empire : gender, race, and the making of British

Columbia, 1849-1871

(Studies in gender and history series)

Includes bibliographical references and index.

ISBN 0-8020-4797-1 (bound) ISBN 0-8020-8336-6 (pbk.)

1. British Columbia - History - 1849-1871.* 2. British Columbia Social conditions - To 1871. 3. British Columbia - Colonization.

I. Title. II. Series.

FC3822.P47 $2001 \quad 971.1^{\prime} 02 \quad$ C00-931748-1

F1088.P47 2001

University of Toronto Press acknowledges the financial assistance to its publishing program of the Canada Council for the Arts and the Ontario Arts Council.

This book has been published with the help of a grant from the Humanities and Social Sciences Federation of Canada, using funds provided by the Social Sciences and Humanities Research Council of Canada.

University of Toronto Press acknowledges the financial support for its publishing activities of the Government of Canada through the Book Publishing Industry Development Program (BPIDP). 